\title{
Microhabitat preferences of Maculinea teleius (Lepidoptera: Lycaenidae) in a mosaic landscape
}

\author{
PÉTER BATÁRY*, NoÉMI ÖRVÖSSY*, ÁDÁM KÖRÖSI, MARIANNA VÁLYI NAGY and LÁSZLÓ PEREGOVITS \\ Hungarian Natural History Museum, Ludovika tér 2., H-1083 Budapest, Hungary; e-mail: batary@nhmus.hu
}

Key words. Lycaenidae, Maculinea teleius, microhabitat, habitat use, foodplant, host ant, grazing, wet meadow

\begin{abstract}
The Scarce Large Blue (Maculinea teleius) is an endangered butterfly throughout Europe due to its special life-cycle and habitat loss. Our aims were to describe the microhabitats available to this butterfly, to test what factors influence the presence and density of M. teleius adults and to investigate the relationship between host ant species and M. teleius. The vicinities of eight fens were sampled, where there are four types of microhabitats available for this butterfly: Narrowleaf Cattail (Typha angustifolia), Purple Loosestrife (Lythrum salicaria), Marsh Woundwort (Stachys palustris) and Purple Moorgrass (Molinia coerulea) dominated vegetation. In five transects $(50 \times 5 \mathrm{~m})$ around each fen (running from the edge of the fen into the meadows) the number of imagos was counted twice a day during the flight period. Along the transects, the following parameters were measured or assessed: number of flowerheads of foodplant (Sanguisorba officinalis), microhabitat type, grazing intensity, soil humidity, vegetation height and host ant presence. The four microhabitat types differed significantly in soil humidity, vegetation height, foodplant density and distance from a fen. Generally the Typha microhabitat, situated closest to fens, had the highest soil humidity and vegetation height, followed by the Lythrum, Stachys and finally the Molinia microhabitat along a gradient decreasing soil humidity and vegetation height. The foodplant was most abundant in the Lythrum and Stachys microhabitats. Using linear mixed models and forward stepwise manual selection we found that microhabitat type was the most important factor determining the presence of M. teleius. The local grazing intensity had no direct effect but flowerheads of the foodplant had a positive effect on the abundance of butterflies. The number of butterflies was significantly higher in quadrats where the host ant (Myrmica scabrinodis) was present compared to those where they were absent. Our results suggest that grazing should be continued in order to maintain the current distribution of microhabitats and survival of the butterflies.
\end{abstract}

\section{INTRODUCTION}

Wet meadows are among the most important habitats of threatened butterflies in Europe (Kühn et al., 2005). More than half of the Hungarian Prime Butterfly Areas (PBA) are wet meadows (Van Swaay \& Warren, 2003). It is now widely demonstrated that agricultural intensification (e.g. intense grazing, land drainage or improvement of grasslands) reduces the diversity and abundance of butterflies associated with extensively managed wet meadows (e.g. Van Swaay \& Warren, 1999; Konvička et al., 2003; Zimmermann et al., 2005). Furthermore, as a result of changes in human land-use, the extensively managed semi-natural meadows have become increasingly fragmented (Kéry et al., 2001). In semi-natural habitats, vegetation structure, habitat features, such as microhabitat factors or management (grazing, mowing) and even ecological processes (e.g. the relationship between butterflies and ants) are important elements in determining the distribution of butterflies (Ravenscroft, 1994; Witek et al., 2006).

Maculinea butterflies are among the most intensively studied butterfly conservation model systems due to their special life cycle, endangered condition and because it is widely recognised that they are sensitive indicators of environmental change (New et al., 1995; Settele et al., 2005). Our study species, the Scarce Large Blue (Macu- linea teleius, Bergsträsser, 1779), is an endangered butterfly throughout Europe (Van Swaay \& Warren, 2003). Threats such as abandonment of traditional agriculture and habitat loss endanger the species in Hungary, although there are still several large populations (Bálint, 1991; Van Swaay \& Warren, 2003). M. teleius breeds in wet meadows and oviposits in the flowerheads of its foodplant, Great Burnet (Sanguisorba officinalis). Therefore the butterfly's distribution strongly depends on the distribution of the host plant (Thomas, 1984). The species is obligately myrmecophilous (Thomas et al., 1989), the host ant species in the study area is Myrmica scabrinodis (Ylander, 1846) (Tartally \& Csősz, 2004; Csősz et al., unpubl.). Young caterpillars - after developing to the final larval stage in the flowerheads of Great Burnet - are adopted by their host ants (Thomas, 1984). In the ant nests the caterpillars live as social parasites, i.e. prey on the ant brood until they complete their development the following year.

Figurny \& Woyciechowski (1998) observed that $M$. teleius, in contrast to the sympatric species M. nausithous (Bergsträsser, 1779), oviposits on the younger and shorter flowerheads that are closer to the ground and have fewer flowers. However, the abundance of flowerheads at an appropriate stage of developement can be greatly affected by management (Johst et al., 2006). The habitat requirements of the early stages (eggs or larvae) are usually nar-

\footnotetext{
* Both authos contributed equally to the paper.
} 
rower and more specialised than that of the imago, so these stages determine the distribution of the butterfly (Ellis, 2003). Therefore, it is only when the niches of foodplant and host ant overlap that Maculinea populations persist, i.e. sufficient eggs must be laid within the foraging range of its host Myrmica colonies (Thomas et al., 1998).

We selected extensively grazed pastures around eight closely adjoining fens on the Hungarian Great Plain. The surrounding of each fen is characterised by a mosaic of swamp meadows, calcareous purple moorgrass meadows and salt steppes, which host different subpopulations of M. teleius (Körösi et al., unpubl.). Our aims were to describe the microhabitats available for the butterfly around the fens, to determine the factors that influence the presence and density of $M$. teleius and finally to investigate the relationship between host ant species and M. teleius.

\section{MATERIAL AND METHODS}

The study area is situated at Kunpeszér, on the Hungarian Great Plain (Central Hungary, Kiskunság National Park). In the study area the mean annual temperature is about $10.3^{\circ} \mathrm{C}$ and mean annual precipitation about $520 \mathrm{~mm}$. This large area (some hundreds of hectares) is a mosaic of fens and meadows. The patchiness of the area is due to the variation in local topography affecting soil humidity. Fens, situated in the most humid and deepest depressions, are characterised by willow bushes and reed and are not suitable habitats for this butterfly. Eight fens of a comparable size were selected (mean $=2.8$ ha, range $=0.8-5.4$ ha). Around them four types of microhabitat were available for this butterfly: vegetation dominated by Narrowleaf Cattail (Typha angustifolia, hence Typha microhabitat), by Purple Loosestrife (Lythrum salicaria, Lythrum microhabitat), by Marsh Woundwort (Stachys palustris, Stachys microhabitat) and by Purple Moorgrass (Molinia coerulea, Molinia microhabitat). The study area had been grazed by cattle for at least 5 years from early spring until late autumn. The cattle density was about 0.3 cows per hectare, and the grasslands were never fertilised or treated with pesticides.

Five $50 \mathrm{~m}$ long and $5 \mathrm{~m}$ wide transects were laid out at each marshland fen, from the edge of the fen perpendicularly outwards to the meadows and as far as possible from each other (Fig. 1). Transects were divided into ten $5 \times 5$ m quadrats $(400$ quadrats in total). The number of $M$. teleius individuals was recorded in each quadrat by walking along each transect in 2 minutes, usually twice a day (when weather conditions allowed) during the flight period from $31^{\text {st }}$ of July to $25^{\text {th }}$ of August in 2005 , i.e. altogether 28 times. Observations on butterflies were carried out on relatively sunny, calm days, the first from 9:00 a.m. in the morning and second in the afternoon up to 4:00 p.m. Parallel to this study the basic population parameters of $M$. teleius were surveyed at the most populated fen (fen "A", see Fig. 1) using the MRR method. The daily number of individuals was about 500-700 and the population at fen "A" was around 2000 individuals, which means that the whole study area could support several thousands butterflies (Örvössy et al., unpubl.).

During the flight period we measured or assessed some local factors in the quadrats, which might be in association with the presence and density of the study species. We counted the number of foodplant flowerheads, measured soil humidity and vegetation height, and classified microhabitat type and grazing intensity in every quadrat. Soil humidity was based on a measure of the electrical conductivity at the end of the flight

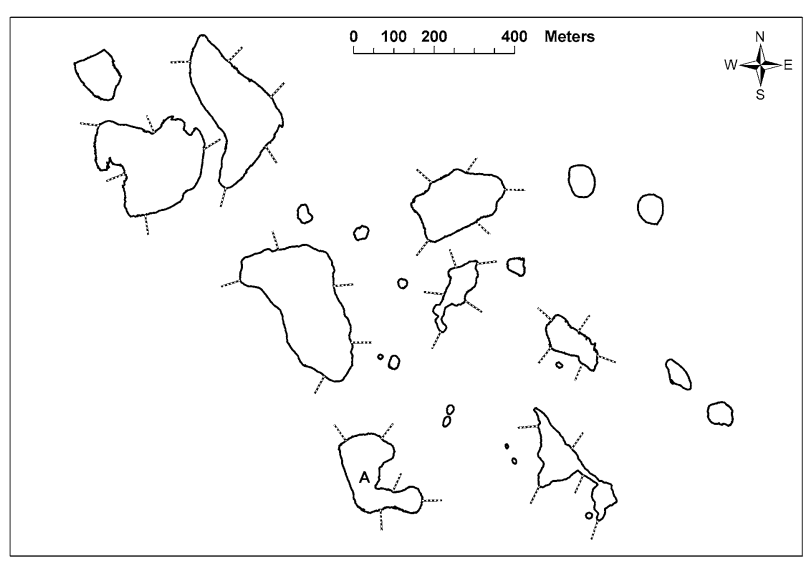

Fig. 1. Map of the study area. The fens are outlined by black lines, while the dashed lines indicate the transects. In the middle of the bottom part of the map is the most heavily populated fen (fen "A").

period. Vegetation height was measured at five random points in each quadrat and means of these measurements were used in the analyses. Grazing intensity was classified as absent, light or strong, based on the incidence of chewing and trampling. Furthermore, pitfall traps containing glycol were used to detect the presence of host ant species. One trap was placed in every second quadrat for two weeks shortly after the flight period. Thirty-two of the traps were lost due to trampling by cattle.

Since the species was not present in 209 quadrats, a logistic regression analysis was used to determine the relationship between presence of butterflies and explanatory variables. A nested design was used with transects nested within fens and quadrats within transects. A forward manual stepwise selection was made, and the null model had the presence-absence of the butterfly as the dependent variable, the number of foodplant flowerheads as the first covariate and fen and transect as random factors. Then, one by one all variables (soil humidity, grazing category, microhabitat type and vegetation height) were added until the best model was obtained (one with the smallest AIC value). Further, we took into account that the quadrats within a transect probably are not correlated equally with each other. Therefore, a correlation between the quadrats was built into the models, which were nested in transects. In this way it was possible to avoid edge effects causing bias in the models.

In the case of fen "A", where the most butterflies were observed, a linear regression analysis was carried out. The $\log _{10}$ transformation of the number of butterflies observed per quadrat was the dependent variable. In addition, the null model contained the number of foodplant flowerhead as the first covariate, the transect as a random factor and the above described correlation. Then the same forward manual stepwise selection procedure was applied as in the case of the logistic regression.

The comparisons between microhabitat types and distance from the fen, soil humidity, foodplant flowerhead density and vegetation height were tested using the Kruskal-Wallis test. The relationship between the number of Maculinea teleius and Myrmica scabrinodis was analysed using a Mann-Whitney test. All statistical analyses were performed using $\mathrm{R}$ software packages (R Development Core Team, 2004).

\section{RESULTS}

The position of the microhabitat types depends on the distance from the fen, usually in the order Typha microhabitat (edge of the fen), Lythrum microhabitat, Stachys 

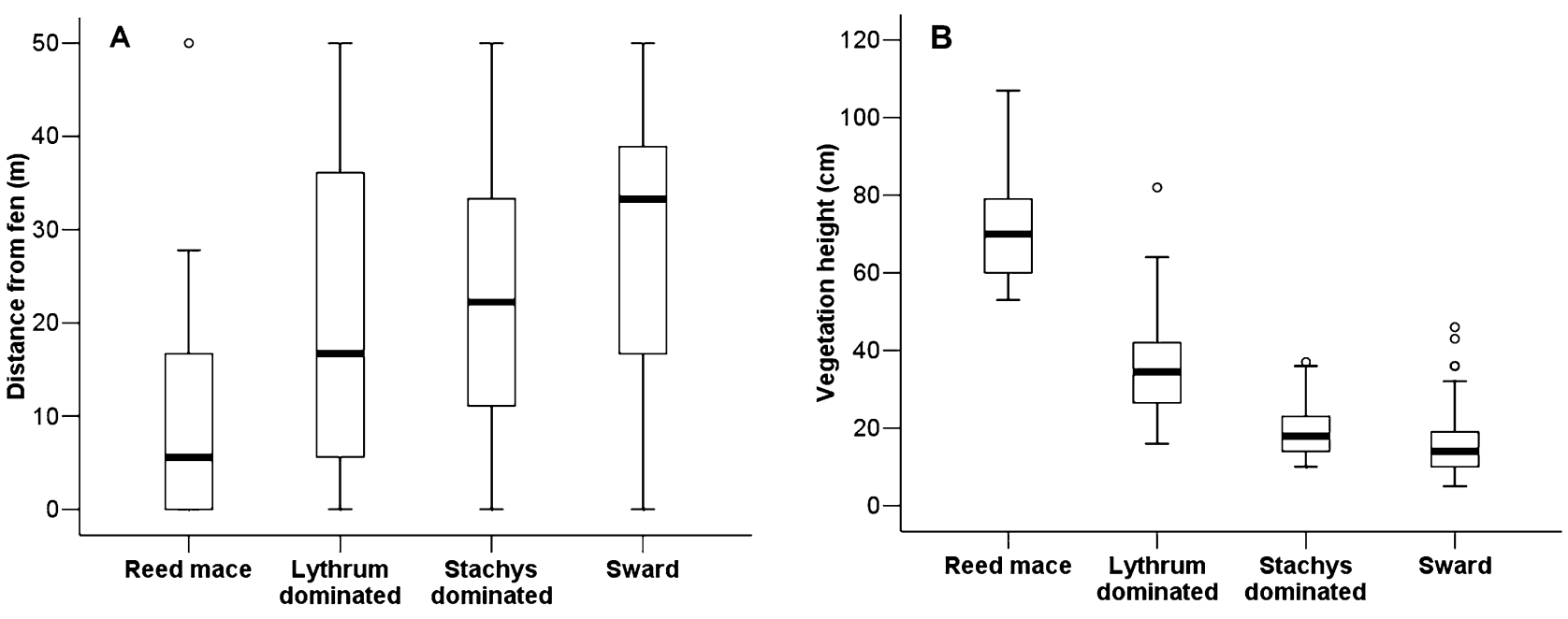

Fig. 2. Medians, quartiles and ranges of the four microhabitat types in terms of distance from a fen (A) and vegetation height (B). The circles indicate outliers.

microhabitat and Molinia microhabitat, furthest from the fen (Fig. 2a). This distribution is not a rigid one, as some of the microhabitats may not be present or not in this order. There are significant differences in the distances of four microhabitats from the edge of the fens (KruskalWallis test; $\chi^{2}=55.2$, d.f. $=3, p<0.001$ ). This is due to differences in topography and soil humidity. There are significant differences in soil humidity (Kruskal-Wallis test; $\chi^{2}=176.6$, d.f. $\left.=3, \mathrm{p}<0.001\right)$ and vegetation height among microhabitats $\left(\chi^{2}=235.4\right.$, d.f. $\left.=3, \mathrm{p}<0.001\right)$. The highest vegetation was at the edges of fens and declined along the transects as microhabitat types changed (Fig. $2 b$ ). The foodplant flowerhead density was significantly higher in the Lythrum and Stachys than in Typha and Molinia microhabitats $\left(\chi^{2}=62.1\right.$, d.f. $\left.=3, \mathrm{p}<0.001\right)$.

The best nested logistic regression model showed a significant effect for microhabitat type, but no effect of foodplant or grazing (Table 1). M. teleius seemed to prefer Stachys and Molinia microhabitats, where the butterfly was recorded in more of the quadrats, than in the Lythrum and Typha microhabitats, which were much less preferred (Fig. 3).

Altogether, there were obtained 553 individual sightings of butterflies, 290 were at the most populated fen (fen " $A$ "). In the best linear regression model butterfly abundance was affected significantly by the number of foodplant flowerheads but not by grazing (Table 1). The abundance of $M$. teleius increased with the number of flowerheads (Table 1, Fig. 4).

Over the whole area the number of M. teleius was significantly higher in quadrats where host ants (Myrmica scabrinodis) were present compared to quadrats lacking the host ant (Mann-Whitney test, $U=2612.5, \mathrm{p}=0.003$ ).

\section{DISCUSSION}

In this study microhabitat type was the most important factor determining the presence of $M$. teleius imagos in a large mosaic landscape (Stachys microhabitats were the most preferred), whereas at the most populated fen, only the density of foodplant flowerheads influenced the abundance of butterflies. However, the foodplant density was different in the microhabitats, the highest density occurred in Stachys and Lythrum microhabitats. This also means that the drier and shorter Molinia microhabitats, which were generally furthest from the fens and the wetter and higher Typha microhabitats close to the fens probably simply act as a matrix for the butterflies. Thomas \& Elmes (2001) found that the foodplants preferred by $M$. teleius were most abundant in short (0-30 $\mathrm{cm})$ vegetation in France and Poland. This is similar to our results, as in the Stachys microhabitat the range in vegetation height was $10-36 \mathrm{~cm}$ for the whole area, while at the fen "A" it was $16-34 \mathrm{~cm}$ and in the Lythrum microhabitat $22-44 \mathrm{~cm}$. So this butterfly species seems to have similar vegetation height requirements in this region as in

TABLE 1. Effects of foodplant flowerhead density, grazing, microhabitat type, soil humidity and vegetation height on the presence (logistic regression) and abundance (linear regression) of M. teleius based on the transect counting method. The best models, after forward manual stepwise model selection do not contain all the explanatory variables. The results for the logistic regression were derived from all 40 transects at the eight fens, while the linear regression used only the data for the fen where the butterflies were most frequently recorded. Variance components of the logistic and linear regression models: random effect $=0.780$, residuals $=$ 0.934 ; random effect $=0.262$, residuals $=0.271$.

\begin{tabular}{|c|c|c|c|c|c|c|c|c|}
\hline & \multicolumn{4}{|c|}{ Logistic regression } & \multicolumn{4}{|c|}{ Linear regression } \\
\hline & numDF & denDF & $\mathrm{F}$ & $\mathrm{p}$ & numDF & denDF & $\mathrm{F}$ & $\mathrm{p}$ \\
\hline Foodplant flowerhead & 1 & 354 & 0.008 & 0.928 & 1 & 42 & 10.956 & 0.002 \\
\hline Grazing & 2 & 354 & 1.229 & 0.294 & 1 & 42 & 1.018 & 0.370 \\
\hline Microhabitat type & 3 & 354 & 2.846 & 0.038 & & & & \\
\hline
\end{tabular}




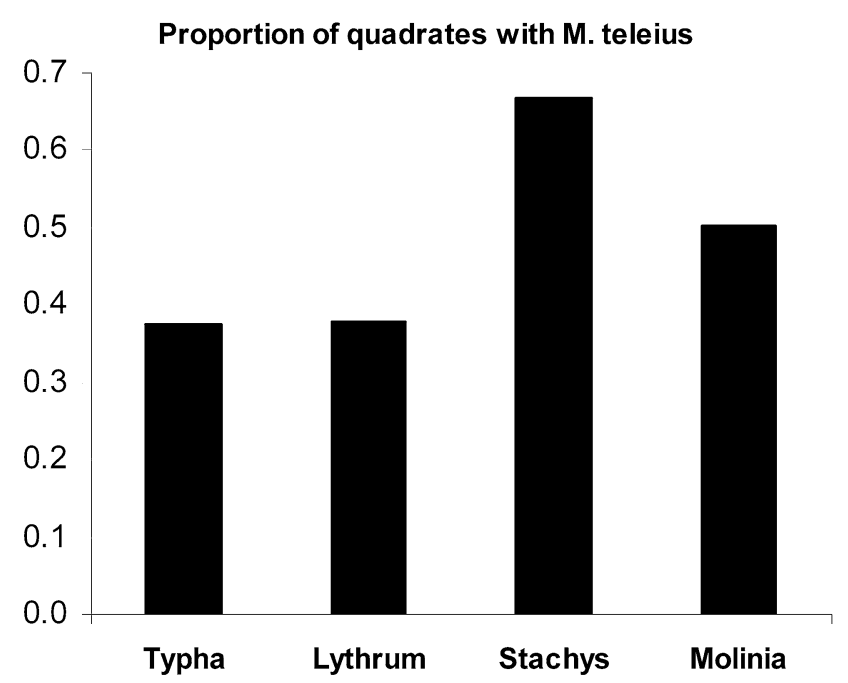

Fig. 3. Proportion of quadrats on each of the four microhabitats in the whole study area where M. teleius was present.

other parts of Europe. Furthermore, with increase in foodplant density the abundance of butterflies increased at the most populated fen. In contrast to our result, which comes from one fen, Nowicki et al. (2005a) found that at a metapopulation level foodplant density limits the abundance of M. alcon [(Denis \& Schiffermüller), 1775], but not that of M. teleius and M. nausithous, while Loritz \& Settele (2005) showed that foodplant availability affects M. nausithous occupancy. Furthermore, Anton et al. (2005) showed that the density of $M$. nausithous is positively correlated with the density of its host ant M. rubra (L., 1758), but not with that of its foodplant $S$. officinalis. Our result can be explained by butterflies occurring mainly at those sites where their foodplants are abundant. However, microenvironmental factors (e.g. soil humidity) determine foodplant abundance and type of microhabitat, so microenvironmental factors and microhabitat types probably have direct and indirect effects on the butterfly.

For the conservation of endangered species, it is important to maintain the quality of this remaining habitats (Maes et al., 2004; WallisDeVries, 2004, Johst et al., 2006). The present study did not indicate that local grazing intensity had a direct effect on butterfly occurrence or abundance. We did not compare sites with different grazing intensity or regimes as in other studies (e.g. Griebeler \& Seitz, 2002; WallisDeVries, 2004), because the whole area was subject to the same management, but measured grazing by means of indicators of chewing and trampling by cattle. However, the low grazing pressure recorded is probably adequate management for this study site. Therefore, like others (Thomas, 1990; Griebeler \& Seitz, 2002), we also think that grazing results in a particular vegetation height and cover of grassland favourable for the butterfly and especially its host ants.

Van Dyck et al. (2000) concluded that host-ant nests (either directly or indirectly) could influence oviposition in M. alcon. Thomas \& Elmes (2001) did not accept that M. alcon can detect ant nests before oviposition. The fact that there was not an ant trap in each quadrat prevented

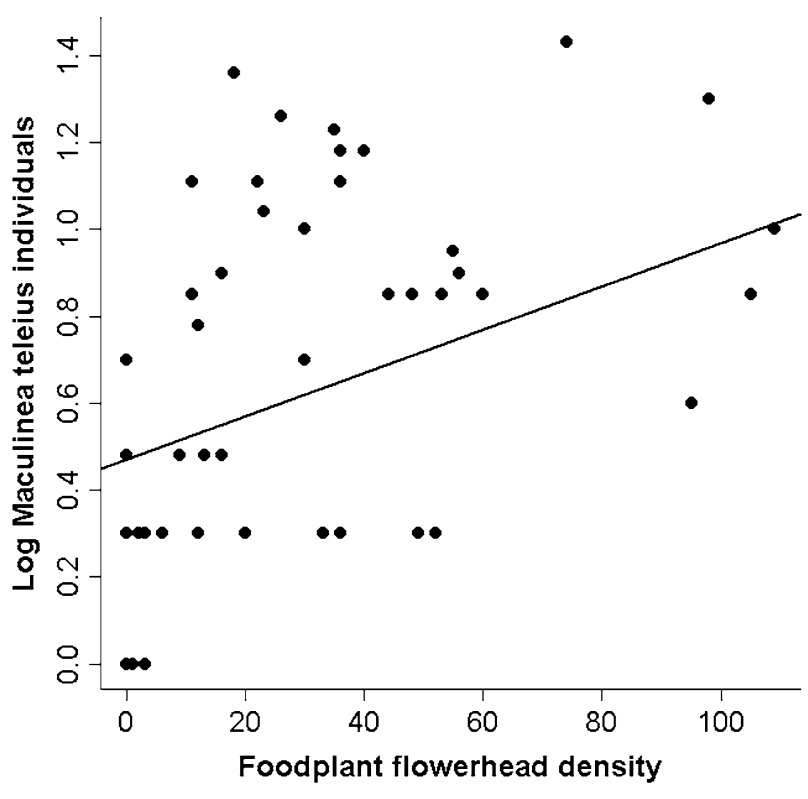

Fig. 4. Relationship between number of foodplant flowerheads per quadrate and the logarithm of $M$. teleius abundance at the most heavily populated fen. The solid line represents the fixed effect of the linear mixed model.

the inclusion of host ant presence in the models and so it was only possible to test separately the relationship between host ant presence and M. teleius abundance. Though butterfly abundance was significantly higher in quadrats in which the host ant was present, this study is too limited to decide if this butterfly is directly or indirectly affected by the presence of host ants. But we draw attention to the fact that lower host ant density can increase the risk of local extinction (Thomas, 1994). However, most studies do not find a significant relationship between host ant presence and abundance of $\mathrm{Macu}$ linea imagos or eggs (e.g. Bonelli et al., 2005; Musche et al., 2005; Nowicki et al., 2005b; Prondvai et al., 2005; but see Anton et al., 2005; Glinka \& Settele, 2005).

The implication for conservation is that grazing should be continued in order to maintain the current distribution of microhabitats. However, it must be emphasised that the grazing intensity in this study was about 0.3 cattle/ha, which is lower than the scheme prescribed in the current Hungarian Agri-Environment Program (0.5-1.2 cattle/ha depending on pasture productivity, Ángyán et al., 2003).

ACKNOWLEDGEMENTS. Four anonymous referees provided constructive remarks that considerably improved the manuscript. We are indebted to F. Samu and S. Csősz for valuable comments on the manuscript and to D. Mayhew for linguistic revision. We thank C. Czinder, M. Kocsis, M. Lörincz and Á. Vozár for help in the field and Y. Clough and A. Harnos for help with the statistics. We are grateful to A. Máté, staff member of the Kiskunság National Park, who gave valuable help. We thank the Kiskunság National Park for permission to carry out this study. The study was supported by the EU-funded project "MacMan" (EVK2-CT-2001-00126) and by the nationally funded "Faunagenesis" project (NKFP 3B023-04). 


\section{REFERENCES}

ÁngyÁn J., Tardy J. \& VAJnÁnÉ-Madarassy A. (eds) 2003: Essentials of Farming on Protected and Environmentally Sensitive Areas. Mezőgazda, Budapest, 625 pp. [in Hungarian])

Anton C., Musche M., Hula V. \& Settele J. 2005: Which factors determine the population density of the predatory butterfly Maculinea nausithous? In Settele J., Kühn E. \& Thomas J.A. (eds): Species Ecology along a European Gradient: Maculinea Butterflies as a Model. Studies on the Ecology and Conservation of Butterflies in Europe. Vol. 2. Pensoft, Sofia, pp. 57-59.

BÁLINT Z. 1991: Conservation of Butterflies in Hungary. Oedippus. 3: 5-36.

Bonelli S., Crocetta A., Barbero F. \& Balletto E. 2005: Oviposition behaviour in the myrmecophilous butterfly Maculinea alcon (Lepidoptera: Lycenidae). In Settele J., Kühn E. \& Thomas J.A. (eds): Species Ecology along a European Gradient: Maculinea Butterflies as a Model. Studies on the Ecology and Conservation of Butterflies in Europe. Vol. 2. Pensoft, Sofia, pp. 65-68.

ELLIS S. 2003: Habitat quality and management for the northern brown argus butterfly Aricia artaxerxes (Lepidoptera: Lycaenidae) in North East England. Biol. Conserv. 113: 285-294.

FigurNy E. \& WoyciechowsKi M. 1998: Flowerhead selection for oviposition by females of the sympatric butterfly species Maculinea teleius and M. nausithous (Lepidoptera: Lycenidae). Entomol. Gener. 23: 215-222.

Glinka U. \& Settele J. 2005: The effect of ant communities and spatial pattern for Maculinea nausithous. In Settele J., Kühn E. \& Thomas J.A. (eds): Species Ecology along a European Gradient: Maculinea Butterflies as a Model. Studies on the Ecology and Conservation of Butterflies in Europe. Vol. 2. Pensoft, Sofia, p. 72.

Griebeler E.M. \& Seitz A. 2002: An individual based model for the conservation of the endangered Large Blue Butterfly, Maculinea arion (Lepidoptera: Lycaenidae). Ecol. Model. 156: $43-60$.

Johst K., Drechsler M., Thomas J. \& Settele J. 2006: Influencing of mowing on the persistence of two large blue butterfly species. J. Appl. Ecol. 43: 333-342.

Kéry M., Matthies D. \& Fischer M. 2001: The effect of plant population size on the interactions between the rare plant Gentiana cruciata and its specialized herbivore Maculinea rebeli. J. Ecol. 89: 418-427.

KonviČKa M., Hula V. \& FRIC Z. 2003: Habitat of prehibernating larvae of the endangered butterfly Euphydryas aurinia (Lepidoptera: Nymphalidae): What can be learned from vegetation composition and architecture? Eur. J. Entomol. 100: 313-322.

Kühn E., Feldmann R., Thomas J. \& Settele J. 2005: Ecology and Conservation of Butterflies in Europe. Studies on the Ecology and Conservation of Butterflies in Europe. Vol. 1. Pensoft, Sofia, $128 \mathrm{pp}$.

Loritz H. \& Settele J. 2005: Effects of human land-use on availability and quality of habitats of the Dusky Large Blue butterfly. In Settele J., Kühn E. \& Thomas J.A. (eds): Species Ecology along a European Gradient: Maculinea Butterflies as a Model. Studies on the Ecology and Conservation of Butterflies in Europe. Vol. 2. Pensoft, Sofia, pp. 225-227.

Maes D., Vanreusel W., Talloen W. \& Van Dyck H. 2004: Functional conservation units for the endangered Alcon Blue butterfly Maculinea alcon in Belgium (Lepidoptera: Lycaenidae). Biol. Conserv. 120: 229-241.
Musche M., Anton C., Worgan A. \& Settele J. 2005: Do ant cues influence the oviposition preference in the myrmecophilous Maculinea nausithous? In Settele J., Kühn E. \& Thomas J.A. (eds): Species Ecology along a European Gradient: Maculinea Butterflies as a Model. Studies on the Ecology and Conservation of Butterflies in Europe. Vol. 2. Pensoft, Sofia, pp. 80-81.

Nowicki P., Pępkowska A., Kudıek J., Skórka P., Witek M. \& WOYCIECHOWSKI M. 2005a: Landscape scale research in butterfly population ecology - Maculinea case study. In Settele J., Kühn E. \& Thomas J.A. (eds): Species Ecology along a European Gradient: Maculinea Butterflies as a Model. Studies on the Ecology and Conservation of Butterflies in Europe. Vol. 2. Pensoft, Sofia, pp. 140-143.

Nowicki P., Witek M., Skórka P., Settele J. \& Woyciechowski M. 2005b: Population ecology of the endangered butterflies Maculinea teleius and M. nausithous and the implications for conservation. Popul. Ecol. 47: 193-202.

New T.R., Pyle R.M., Thomas J.A., Thomas C.D. \& Hammond P.C. 1995: Butterfly conservation management. Annu. Rev. Entomol. 40: 57-38.

Prondvai E., Kassai F., Csősz S., Árnyas E., Bereczki J., Tóth A., Varga Z., Peregovits L. \& Kis J. 2005: Oviposition in Maculinea alcon butterflies. In Settele J., Kühn E. \& Thomas J.A. (eds): Species Ecology along a European Gradient: Maculinea Butterflies as a Model. Studies on the Ecology and Conservation of Butterflies in Europe. Vol. 2. Pensoft, Sofia, pp. 82-83.

R Development Core Team 2004: R: A language and environment for statistical computing. Foundation for Statistical Computing, Vienna; URL: http://www.R-project.org.

RAVENSCROFT N.O.M. 1994: The ecology of chequered skipper butterfly Carterocephalus palaemon in Scotland. I. Microhabitat. J. Appl. Ecol. 31: 613-622.

Settele J., Kühn E. \& Thomas J.A. 2005: Species Ecology along a European Gradient: Maculinea Butterflies as a Model. Studies on the Ecology and Conservation of Butterflies in Europe. Vol. 2. Pensoft, Sofia, 289 pp.

TARTAlly A. \& Csösz S. 2004: Data on the ant hosts of the Maculinea butterflies (Lepidoptera: Lycenidae) of Hungary. Termvéd. Közl. 11: 309-317 [in Hungarian, English abstract].

THomas J.A. 1984: The behaviour and habitat requirement of Maculinea nausithous (the Dusky Large Blue Butterfly) and M. teleius (the Scarce Large Blue) in France Biol. Conserv. 28: $325-347$.

Thomas J.A. 1990: Rare species conservation: case studies of European butterflies. In Spellerberg I.F., Goldsmith F.B. \& Morris M.G. (eds): The Scientific Management of Temperate Communities for Conservation. Blackwell Scientific Publications, Oxford, pp. 149-197.

Thомаs J.A. 1994: The ecology and conservation of Maculinea arion and other European species of large blue. In Pullin A. (ed.): Ecology and Conservation of Butterflies. Chapman \& Hall, London, pp. 180-196.

Thomas J.A. \& Elmes G.W. 2001: Food-plant niche selection rather than the presence of ant nests explains oviposition patterns in the myrmecophilous butterfly genus Maculinea. Proc. R. Soc. Lond. (B) 268: 471-477.

Thomas J.A., Elmes G.W., Wardlaw J.C. \& Woyciechowski M. 1989: Host specificity among Maculinea butterflies in Myrmica ant nests. Oecologia 79: 452-457.

Thomas J.A., Clarke R.T., Elmes G.W. \& Hochberg M.E. 1998: Population dynamics in the genus Maculinea (Lepidoptera: Lycenidae). In Dempster J.P. \& McLean I.F.G. (eds): Insect Populations. Chapman \& Hall, London, pp. 261-290. 
Van Dyck H., Oostermeier J.G.B., Talloen W., Feenstra V., Van der Hidde A. \& Wynhoff I. 2000: Does the presence of ant nests matter for oviposition to a specialized myrmecophilous Maculinea butterfly? Proc. R. Soc. Lond. (B) 267: 861-866.

Van SwaAy C.A.M. \& Warren M.S. 1999: Red Data Book of European Butterflies (Rhopalocera). Nature and Environment Series No. 99. Council of Europe, Strasbourg, $260 \mathrm{pp}$.

Van Swahy C.A.M. \& Warren M.S. 2003: Prime Butterfly Areas in Europe: Priority Sites for Conservation. National Reference Centre for Agriculture, Nature and Fisheries, Ministry of Agriculture, Nature Management and Fisheries, Wageningen, The Netherlands.
WallisDeVRIES M.F. 2004: A quantitative conservation approach for the endangered butterfly Maculinea alcon. Conserv. Biol. 18: 489-499.

Witek M., Sliwinska E.B., Skórka P., Nowicki P., Settele J. \& Woyciechowski M. 2006: Polymorphic growth in larvae of Maculinea butterflies, as an example of biennialism in myrmecophilous insects. Oecologia 148: 729-733.

Zimmermann K., Fric Z., Filipová L. \& KonvičKa M. 2005: Adult demography, dispersal and behaviour of Brenthis ino (Lepidoptera: Nymphalidae): how to be a successful wetland butterfly. Eur. J. Entomol. 102: 699-706.

Received August 12, 2007; revised and accepted June 20, 2007 